\title{
The Predictive Role of Academic Hope in Academic Procrastination Among Students: a Mixed Methods Study
}

\author{
Zummy Anselmus Dami ${ }^{1}$, Sance Mariana Tameon ${ }^{2}$, Jeheskial Saudale ${ }^{3}$ \\ Universitas Persatuan Guru 1945 NTT, Faculty of Education, Indonesia, ID-85119, zummydami82@gmail.com \\ Department of Pastoral Counseling, Sekolah Tinggi Agama Kristen Negeri Kupang, Indonesia, ID-85111, \\ sancemariana82@gmail.com \\ Department of Christian Religious Education, Sekolah Tinggi Agama Kristen Kupang, Indonesia, ID-85112, \\ jeheskiel.saudale@gmail.com
}

\begin{abstract}
The aim of the current study was to investigate the correlation of academic hope with academic procrastination; to determine the differences in the academic procrastination of both men and women; to understand why students conduct academic procrastination; and to know the academic hope of students. The study uses a mixed-method research design. The results showed that academic hope has a positive and significant correlation with academic procrastination; there is no significant difference between male and female students in any scale of academic hope and academic procrastination; the reason students conduct procrastination is "I generally delay before starting on work I have to do"; and the academic hope students are unique because it relates to God and parents.
\end{abstract}

Keywords: academic hope, academic procrastination, mixed-methods, reason procrastination, uniqueness hope.

\section{Introduction}

There are many responsibilities and obligations that students should take in their academic lives that affect their efficiency and success at school. As part of their responsibilities in fulfilling their academic obligations, they are confronted with one of the most important problems, namely procrastination behaviour (Y1ld1z \& Y1ld1z, 2016, 234; 
Akpur, 2017, 222). The procrastination behaviour of school duties is a common problem among students, and it is the main cause of failure or absence of success in the learning and enhancement of academic achievement (Narges, Sahar, \& Salman, 2014, 259).

The term procrastination is derived from the Latin word procrastinus; pro means precursor and crustiness means tomorrow, while the combination of the two words contains meaning to postpone, delay, prolong, postpone or fail to perform a task (Asif, 2011). In this aspect, procrastination is seen as 'Tomorrow Syndrome' (Knaus, 2002). Procrastination can also be referred to as a style of self-regulation that delays initiating or terminating a task (Ferrai \& Tice, 2000), or in other words, an act that tends to delay or avoiding in deciding to achieve a goal (Lay, 1986; Levy, 2010). What is expressed in these definitions is that the most important aspect of procrastination is a task that is not carried out within a certain period, whereas there is sufficient time to do so. Furthermore, based on these definitions, it is pointed out that procrastination is a complex process as it includes the affective, cognitive, and psychomotor components (Rothblum, Solomon, \& Murakami, 1986). It proves that procrastination as a personality characteristic is much more than time management (Özer \& Saçkes, 2011).

One type of procrastination that has received much attention from researchers is academic procrastination and is one of the most common types (Moonaghi, Baloochi, \& Beydokhti, 2017,44). This type of procrastination is an unwarranted desire to delay start working on the duties of subjects or academics (Özer, Demir, \& Ferrari, 2009), such as underestimating the time needed to complete the reading task, skip Deadline to complete and surrender the task, and prepare the exam (Mohammadipour \& Rahmati, 2016). The research results of McCloskey (2011) showed that academic procrastination could be formed due to students' confidence in their abilities, the presence of disgraceful factors (distractor), the influence of the social environment (such as friends), lack of ability to manage time, lack of initiative in starting work and laziness (Akmal, Arlinkasaria, \& Fitriani, 2017).

Concerning the influence of academic procrastination on academic achievements, there have been several studies reporting on different results. Some researchers found academic procrastination to have a negative influence on learning (Aremu, Williams, \& Adesina, 2011) and academic achievement (Van Eerde, 2003). In contrast, other findings suggest that academic procrastination has a positive influence on academic achievement (Brinthaupt \& Shin, 2001). Other studies have also shown that depression, mistakes, low grades, worries, neuroticism, irrational thinking, cheating, and low self-esteem are often associated with academic procrastination (Solomon \& Rothblum, 1984). Nevertheless, in some cases beneficial academic procrastination where students opt for procrastination because it prefers work under pressure, and it is beneficial, but on the other side the academic procrastination never remains an option best of a person (Tripathi et al., 2015).

All students can perform academic procrastination, both with excellent skills and knowledge and who have the ability and knowledge below average (Akmal, Arlinkasaria, 
\& Fitriani, 2017). Academic procrastination is a severe problem in the educational environment (Esmaeili \& Monadi, 2016). Various strategies can be used to reduce academic procrastination. Based on the results of previous studies, social motivation, Positive attitude (Nábělková \& Ratkovská, 2015), consultation, and using self-learning books (Rabin, Fogel, \& Nutter-Upham, 2011) is often used to cope with and reduce procrastination Academic.

In this study, academic hope was used as strategies to overcome and reduction of academic procrastination. Hope is a cognitive construction involving one's expectations to achieve the goal successfully. (Feldman, Davidson, \& Margalit, 2015). Hope can be explained as a one-dimensional structure, including understanding the problems to achieve the objectives (Snyder, 2000). Hope has three components: 1) having specific goals, 2) thinking of crossings which help the person to create passageways to reach the goal, 3) determination, which includes the utilization of a personality's ability to move toward the goal (McDermott \& Snyder, 2000). Feldman's \& Snyder discovers that hopes have a positive relationship with students' academic achievements in high school and university (Narges, Sahar, \& Salman, 2014). Teachers who can inspire the students' academic hope will allow students to imagine and fantasize about the things students will learn (Erikson, 2000).

Previous research results proved that the concept of hope has a significant relationship with academic procrastination (Alexander \& Onwuegbuzie, 2007; Akmal, Arlinkasaria, \& Fitriani, 2017). Conflicting research results show that academic procrastination has a negative relationship with self-efficacy for self-regulation and hope (Narges, Kermanian, \& Zarei, 2014). Other research results also show that hope has a meaningful and negative influence with academic procrastination (Kandermir, 2014).

In addition, in Synder Theory (1994), fundamentally, there is no difference of hope between men and women. Other researchers have also reported similar results that there is no gender difference in hope (Rehmae et al., 2014; Hasnain, Wazid, \& Hasan, 2014). Instead, research rises \& Yadav (2017); Alvi \& Mirza (2018) found that there was a gender difference in hope, where men had a higher score than women. Similar findings were also reported by Gul and Nizami (2015). Gender differences relating to academic procrastination also have controversial issues because it is difficult to predict (Mahasneh et al., 2016). Although some studies have reported significant gender differences (Milgram, 1995; Pychyl, Coplan \& Reid, 2002), another study reported no gender differences (ABU, 2012; Sharma \& Kaur, 2011). Some researchers have mentioned that evidence suggests that women have a higher risk of procrastination than men (Haycocks, McCarthy \& Skay, 1998; Paludi \& Frankell-Hauser, 1986), and women experienced a higher level of procrastination compared to men (Rothblum, Solomon, \& Murakami, 1986). Balkis \& Duru (2009) researched students at Pamukkale University, and the results show that male students are more intent on procrastination. 
Previous studies on the relationship of hope with academic procrastination show inconsistent results and only using quantitative methods. In this research researchers use mixed-method. The objectives of the study can be formulated in the research questions:

1. Is there any relationship between academic hope with academic procrastination?

2. Is there a difference in academic procrastination male and female students?

3. What is the reason why students conduct academic procrastination?

4. What is the academic hope of students for the future?

\section{Methodology}

\section{Model}

The study uses a mixed-method research design, which is a quantitative method integrated with a qualitative method, and then draws conclusions based on both. The quantitative phase help to know the relationship between academic hope with academic procrastination and difference in academic procrastination male and female students. The qualitative phase is used analyzing the reason why students conduct academic procrastination and the academic hope of students for the future.

\section{Participants and Sampling}

The population in this study was 253 students of SMA Kristen 2 Kupang. (Private High School). Respondents were obtained from grade X, XI, \& XII students in the Major of Social Sciences (IIS) and Mathematics and Natural Sciences (MIA) SMA Kristen 2 Kupang (table 1), using a random sampling method. Participants of 115 students with details, 54 are male and 61 female.

Table 1

Respondents by class and majors

\begin{tabular}{lccc}
\hline \multicolumn{1}{c}{ Class } & IIS & MIA & Total \\
\hline $\mathrm{X}$ & 18 & 18 & 36 \\
\hline $\mathrm{XI}$ & 18 & 19 & 37 \\
\hline $\mathrm{XII}$ & 21 & 21 & 42 \\
\hline Total & & & 115 \\
\hline
\end{tabular}

\section{Data Collection Instruments}

Quantitative data was collected using two self-report instruments (closed questionnaire) and one self-report instrument (open questionnaire), while qualitative data was 
developed from partially-structured interview protocol. These three forms of data are independent of one another.

The Hope Scale (HS). Synder et al. (1991), originally developed this scale and adapted by researchers, consisting of 12 items and using a four-point Likert scale by following two sub-scales: (1) Pathways, using four items (1, 4, 6, \& 8); (2) agency, using four items $(2,9,10, \& 12)$. In addition, there are four filler items $(3,5,7, \& 11)$. The scale assessment of each item is in the range between 1 = Definitely False, $2=$ Mostly False $3=$ Mostly True, 4 = Definitely True. There is no reference to the score of items, so a high score is interpretive as a high level of hope. The internal validity of this scale was found to fluctuate between 0.70 and 0.80 .

Procrastination Scale (PS). The scale was developed by Lay (1986) to be used for the student population. This scale has a high reliability $(\alpha=0.876)$. This scale consists of 5 components: (1) Good planning (item: 8, 14, 15, 18 \& 20); (2) Delaying (items: 5, 9, 11, 12 \& 19); (3) Doing thing in last minute (item: $16 \& 17$ ); (4) Good time management (item: 3, 4, 6 \& 13); (5) Poor time management (items: 1, 2, 7 \& 10). In this research researchers used only 18 items in accordance with the context of participants. Assessment for scale Item range 1 = Always be a problem, $2=$ almost always, 3 = sometimes, $4=$ almost never, $5=$ not a problem at all.

The Hope Interview was created by Holt \& Reeves (2001) to collect qualitative data. The question in this instrument consists of 2 big questions, question 1: What is your hope?; Question 2: Why is it important for you?. The qualitative question of this study is aimed at declaring the development of the academic hope of a very influential student and what is the role of culture and religion towards students. Besides, this qualitative question helps provide a trans-discipline perspective in the frame difference culture in Indonesia.

A partially-structured interview protocol is used as the primary guide and allows interviewers to change and add questions (Krathwohl, 1998). These interview questions are open-ended and designed to acquire a profound picture of the student's academic procrastination behaviour. All the students interviewed were first asked to explain when they were procrastination on academic duties. These questions are prepared to encourage participants to engage in topics as they explain their procrastination experience. These questions were also developed to investigate students' perception and various possible reasons for academic procrastination.

\section{Procedure}

At the beginning of the new school year, researchers visited each class and briefly explained the purpose and procedure of this study in order to avoid bias. After students have obtained a comprehensive picture of this study, researchers distribute two closed self-report instruments (closed questionnaire) and one open self-report instrument (open questionnaire) to students. In particular, an open self-report instrument (open questionnaire) is used to know the students' academic hope according to their understanding and 
experience. Students finish the questionnaire in the classroom, and if not complete, it is welcome to solve it at home and bring it back on the day of the interview. Furthermore, researchers make individual counseling schedules to students, and the schedule is sent to the homeroom teacher to be informed to students. Researchers carry out individual interview sessions along with individual counseling to each student to obtain data relating to academic procrastination.

Interviews are conducted individually in the room of guidance and counseling. When students come for an interview session, questionnaires are collected, and then the interview format is briefly explained to the student. Students are told they are free to terminate their participation and refuse to answer the questions without penalty. All interview sessions are recorded using a smartphone. The interview is conducted for 45 minutes (1 session hour lesson) for each student. Within one day, researchers conducted individual interviews of 6 students, and all sessions were completed within four months (August-November 2019).

\section{Data Analysis}

Quantitative data were analyzed using descriptive statistics, Pearson test, and independent t-test tests. All of these testing phases use SPSS Version 18 with the P-value $<0.05$ considered statistically significant. While the data of interviews are made verbatim, make a memo, coding, and analyzed with a focus on procrastination behaviour under academic settings (Creswell \& Plano-Clark, 2007). Before the Pearson and independent t-test analysis, data were tested using reliability coefficients, the normality test (Kolmogorov-Smirnov) and the homogeneity test (Levene's test). The test results showed that the reliability coefficients academic hope of 0.615 and academic procrastination of 0.692 , the test of normality of academic hope 0.452 ( $\mathrm{P}$-value $>0.05$ ) and academic procrastination 0.769 (P-value $>0.05$ ), while test homogeneity of academic hope 0.059 ( $\mathrm{P}$-value $>0.05$ ) and academic procrastination 0.063 (P-value $>0.05$ ), the test results show that all tests are eligible for subsequent analysis.

\section{Results}

Descriptive statistics for all variables are shown in Figure 1. The highest score on the Hope Scale dimension is found in pathways (12.22 \pm 1.648 ), followed by the agency $(11.17 \pm 1.811)$. While the highest score on the dimension of procrastination scale was found in good time management $(12.81 \pm 2.547)$, followed by delaying $(12.76 \pm 2.227)$. On the other, the lowest score in the Hope Scale dimension is found in filler (11.03 \pm 2.013), and the lowest score in the scale procrastination dimension is in doing thing in last minute $(5.71 \pm 1.583)$. 


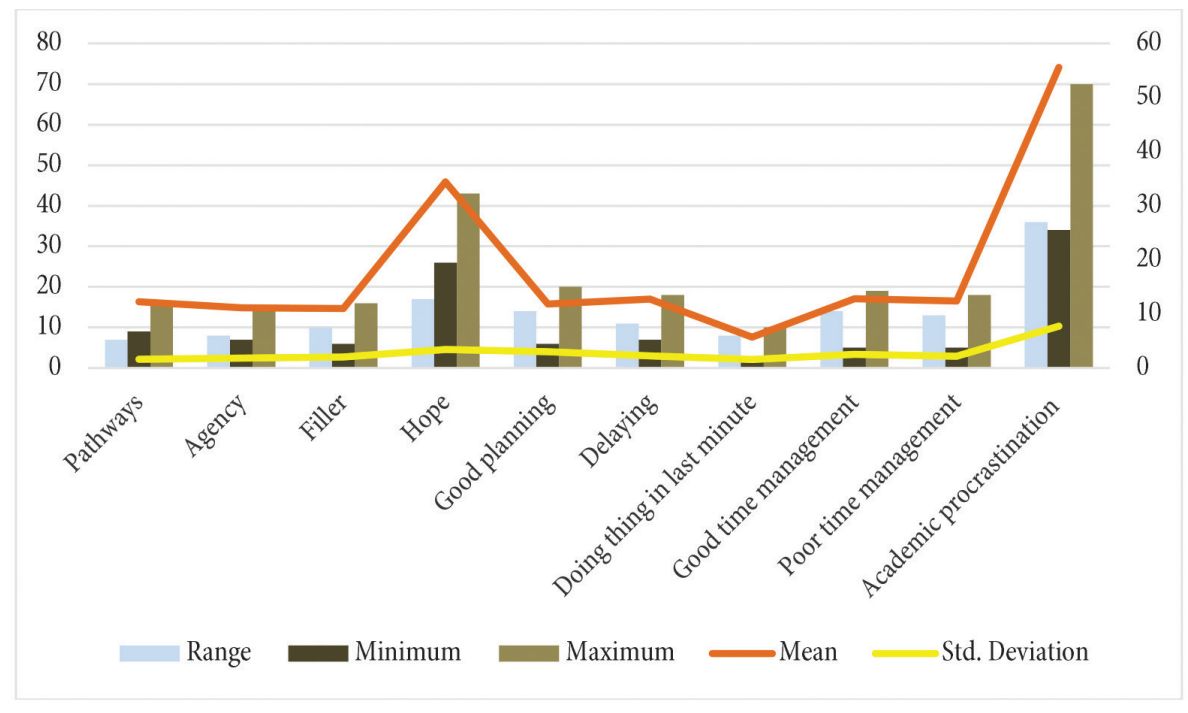

Figure 1. Descriptive statistics for all variables

The results of the analysis showed that the academic hope of students found in moderate category (pathways $63 \%$, agency $54 \%$, and filler $57 \%$, hope scale $78 \%$ ) in table 2 , as well as academic procrastination found in moderate category (good planning 37\%, delaying $47 \%$, Doing thing in last minute $32 \%$, good time management $39 \%$, poor time management $53 \%$, and procrastination scale $65 \%$ ) in table 3 . The highest score of academic hope is found on pathways $63 \%$, and the highest score of academic procrastination is found in poor time management $53 \%$.

Table 2

Profile of academic hope students

\begin{tabular}{lcccccccccc}
\hline \multirow{2}{*}{ Category } & \multirow{2}{*}{ Range } & \multicolumn{2}{l}{ Pathways } & \multicolumn{2}{c}{ Agency } & \multicolumn{2}{c}{ Filler } & \multicolumn{3}{c}{ Hope } \\
\cline { 3 - 12 } & & $\mathbf{N}$ & $\%$ & $\mathbf{N}$ & $\%$ & $\mathbf{N}$ & $\%$ & $\mathbf{N}$ & $\%$ \\
\hline Very high & $4,21-5,0$ & 0 & 0 & 0 & 0 & 0 & 0 & 0 & 0 \\
\hline High & $3,41-4,2$ & 25 & 22 & 11 & 9 & 11 & 10 & 6 & 5 \\
\hline Moderate & $2,61-3,4$ & 73 & 63 & 62 & 54 & 66 & 57 & 89 & 78 \\
\hline Low & $1,81-2,6$ & 17 & 15 & 41 & 36 & 34 & 30 & 20 & 17 \\
\hline Very low & $1,00-1,8$ & 0 & 0 & 1 & 1 & 4 & 3 & 0 & 0 \\
\hline \multicolumn{2}{c}{ Total } & 115 & 100 & 115 & 100 & 115 & 100 & 115 & 100 \\
\hline
\end{tabular}


Table 3

Profile of academic procrastination students

\begin{tabular}{|c|c|c|c|c|c|c|c|c|c|c|c|c|c|}
\hline \multirow{2}{*}{ Category } & \multirow{2}{*}{ Range } & \multicolumn{2}{|c|}{ GP } & \multicolumn{2}{|c|}{ D } & \multicolumn{2}{|c|}{ DTiLM } & \multicolumn{2}{|c|}{ GTM } & \multicolumn{2}{|c|}{ PTM } & \multicolumn{2}{|c|}{ APT } \\
\hline & & $\mathbf{N}$ & $\%$ & $\mathbf{N}$ & $\%$ & $\mathbf{N}$ & $\%$ & $\mathbf{N}$ & $\%$ & $\mathbf{N}$ & $\%$ & $\mathbf{N}$ & $\%$ \\
\hline Very high & $4,21-5,0$ & 10 & 9 & 3 & 3 & 4 & 3 & 6 & 5 & 3 & 3 & 0 & 0 \\
\hline High & $3,41-4,2$ & 24 & 21 & 41 & 35 & 28 & 25 & 41 & 35 & 29 & 25 & 26 & 23 \\
\hline Moderate & $2,61-3,4$ & 42 & 37 & 54 & 47 & 37 & 32 & 45 & 39 & 61 & 53 & 75 & 65 \\
\hline Low & $1,81-2,6$ & 31 & 27 & 16 & 14 & 36 & 31 & 22 & 20 & 20 & 17 & 14 & 12 \\
\hline Very low & $1,00-1,8$ & 8 & 7 & 1 & 1 & 10 & 9 & 1 & 1 & 2 & 2 & 0 & 0 \\
\hline \multicolumn{2}{|c|}{ Total } & 115 & 100 & 115 & 100 & 115 & 100 & 115 & 100 & 115 & 100 & 115 & 100 \\
\hline \multicolumn{14}{|c|}{ GP = Good planning } \\
\hline \multicolumn{14}{|c|}{$\mathrm{D}=$ Delaying } \\
\hline \multicolumn{14}{|c|}{ DTiLM = Doing thing in last minute } \\
\hline \multicolumn{14}{|c|}{ GTM = Good time management } \\
\hline \multicolumn{14}{|c|}{ PTM = Poor time management } \\
\hline $\mathrm{APT}=\mathrm{Aca}$ & demic Proc & stinat & & & & & & & & & & & \\
\hline
\end{tabular}

The first goal of the study was to test the correlation between academic hope with academic procrastination. Table 4 reports the correlation between variables that have been tested. First, as predicted, the hope scale score correlates with the procrastination scale $(\mathrm{p}<.01)$. Pathways have a positive correlation with good planning $(\mathrm{p}<.01)$, doing thing in last minute $(\mathrm{P}<.05)$, good time management $(\mathrm{P}<.01)$, poor time management $(\mathrm{p}<.05)$, and a procrastination scale score $(\mathrm{p}<.01)$.

Table 4

Pearson correlations among variables

\begin{tabular}{|c|c|c|c|c|c|c|c|c|c|c|}
\hline & 1 & 2 & 3 & 4 & 5 & 6 & 7 & 8 & 9 & 10 \\
\hline Pathways & - & .12 & $.39^{\star *}$ & $-.20^{\star}$ & $.56^{\star \star}$ & $.37^{\star *}$ & $.21^{*}$ & $.27^{\star *}$ & $.20^{*}$ & $.37^{\star *}$ \\
\hline Delaying & & - & .16 & .05 & .17 & $.29^{\star *}$ & $.21^{\star}$ & $.20^{*}$ & $.24^{* *}$ & $.58^{\star \star}$ \\
\hline Agency & & & - & .11 & $.78^{\star *}$ & $.24^{* *}$ & $.19^{*}$ & $.18^{*}$ & $.21^{*}$ & $.30^{* *}$ \\
\hline Filler & & & & - & $.54^{\star *}$ & -.04 & -.11 & -.15 & -.05 & -.09 \\
\hline Hope scale & & & & & - & $.28^{\star *}$ & .14 & .13 & .17 & $.28^{* *}$ \\
\hline Good planning & & & & & & - & $.47^{* *}$ & $.41^{\star *}$ & $.32^{* *}$ & $.80^{* *}$ \\
\hline Doing thing in last minute & & & & & & & - & $.34^{* \star}$ & $.32^{* \star}$ & $.65^{\star \star}$ \\
\hline Good time management & & & & & & & & - & .15 & $.66^{* *}$ \\
\hline Poor time management & & & & & & & & & - & $.59^{* *}$ \\
\hline Procrastination scale & & & & & & & & & & - \\
\hline $\mathrm{N}=115,{ }^{* *} \mathrm{p}<.01,{ }^{*} \mathrm{p}<.05$ & & & & & & & & & & \\
\hline
\end{tabular}


The same findings also show that the agency has a positive correlation with good planning $(\mathrm{p}<.01)$, doing thing in last minute $(\mathrm{P}<.05)$, good time management $(\mathrm{P}<.05)$, poor time management $(\mathrm{p}<.05)$, and a procrastination scale score $(\mathrm{p}<.01)$. Conversely, pathways and agency do not correlate with delaying. The findings show that there is no correlation between filler with good planning, doing thing in the last minute, good time management, poor time management, and procrastination scale scores

The second goal achieved in this study is to compare the academic hope and academic procrastination of both men and women. Table 5 shows that the mean and standard deviation male and female are no significant differences in each scale.

Tabel 5

Comparative independent sample t-test on variables based on gender

\begin{tabular}{lccccc}
\hline & \multicolumn{3}{c}{ Man } & \multicolumn{3}{c}{ Woman } \\
\cline { 2 - 6 } & $\mathbf{M}$ & SD & M & SD & $\boldsymbol{\alpha}$ \\
\hline Pathways & 12.22 & 1.610 & 12.21 & 1.694 & 0.977 \\
\hline Agency & 11.04 & 2.037 & 11.28 & 1.593 & 0.478 \\
\hline Filler & 10.63 & 2.059 & 11.39 & 1.917 & 0.042 \\
\hline Hope scale & 33.89 & 3.859 & 34.89 & 2.995 & 0.123 \\
\hline Good Planning & 11.94 & 3.439 & 11.79 & 2.640 & 0.782 \\
\hline Delaying & 13.15 & 2.218 & 12.41 & 2.194 & 0.076 \\
\hline Doing thing in last minute & 5.70 & 1.678 & 5.72 & 1.507 & 0.953 \\
\hline Good time Management & 13.00 & 2.862 & 12.64 & 2.244 & 0.451 \\
\hline Poor time Management & 12.61 & 2.277 & 12.25 & 2.047 & 0.367 \\
\hline Procrastination Scale & 56.41 & 8.645 & 54.80 & 6.819 & 0.269 \\
\hline
\end{tabular}

The study also tested the reasons for supporting students to conduct academic procrastination based on a scale of procrastination. The results of the study showed the percentage of participants, both male and female, who had the reason for supporting the highest of each statement item. The most highly supportive reason for both males and females is "I generally delay before starting on work I have to do". Furthermore, the most highly supported reasons for men are "Did so many other things that there was insufficient time left for studying", "Forgot to prepare things for studying", and "Had doubts about your own ability". As for women is "Had doubts about your own ability", "Found the subject matter boring", and "I am continually saying" I'll do It Tomorrow" (Table 5).

Based on the reason of the dominant supporters in males and females, namely "I generally delay before starting on work I have to do", and then proceed with conducting individual interviews using a partially-structured interview protocol to all respondents, three themes emerged, which includes lack of regulatory skills, working under pressure, and active procrastination. 
A lack of regulatory skills. Many male and female students respond that they usually have planned to work before but end up doing in the last minute. That is, they do not plan to conduct procrastination, but tend to delay what they have planned when they choose to engage in other activities. The following excerpt is an example of how procrastinators describe their delaying behaviour. Procrastinators are also less capable of controlling their own behaviour. They seem to be easily distracted by other interesting activities (did so many other things that there was insufficient time left for studying), and could not make themselves motivated to work as previously planned. Most of them admit that procrastination is not good behaviour, and they demonstrate the intention to reduce such behaviour because they believe that they will perform better without delay; Nevertheless, they seem to continue to procrastinate. Some students even believe that they cannot change their procrastination behaviour.

Working under pressure. There are many students also reporting that they work better under pressure or feel confident working under pressure. What they mean by saying work better under pressure is that they can stay focused on the task that the teacher has given you. It does not necessarily seem to indicate that they will perform better. In contrast, procrastinators admit that they will do a more qualified job if they will not delay and be able to concentrate as they do when working under pressure. They argue that they are procrastinating deliberately to work better if under pressure, and some of them also mention that they have just gotten used to working in a short time after a few examples of delays, and with So they feel quite comfortable working under pressure. The hidden reason is they had doubts about your own ability and found the subject matter boring. Nevertheless, they still report experiencing stress or guilt during a delay and consider delays as bad habits.

Active procrastination. Interestingly, one of the students pointed out that he or others talked about working best under pressure just to justify procrastination. He explained that "I can pretend as if I am procrastinating because I am working better under pressure, so I am continually saying" I will do it tomorrow. I do not think I am more productive when I know I have to do something at some point, and I do not have so much free time. It motivates me to get all that would do... But, maybe, I am just trying to justify why I'm procrastinating. Try to look better. He also said, "I do not think there is a benefit to procrastinate". I think that people just use it as an excuse to say that doing your best is under pressure. In short, procrastinators give a general comment that working better under pressure may not refer to better achievement of results or deliberate delays. This just might mean that they concentrate more on the task under a limited amount of time compared to when there is much amount of time left before the due date, or in other words, it is merely a reason for procrastination.

Among procrastinators, there is a student who reports that he likes to do the last minute work and is under pressure. He thinks he works better under pressure. That is, he is deliberately procrastinating because he can focus and concentrate better on the 
task when there is a limited amount of time, so forgot to prepare things for studying. He expressed strong confidence in working under pressure. He does not seem to feel anxious when procrastinating. He said it because he knew that he could finish it on time. He also never regretted procrastinating because he always ensured that he had enough time to get the job done, and he always received satisfactory results.

Table 6

Percentage of man and woman procrastinators who highly endorsed each item of procrastination scale

\begin{tabular}{|c|c|c|c|}
\hline & $\begin{array}{c}\text { Total } \\
(\mathrm{N}=115)\end{array}$ & $\begin{array}{c}\text { Man } \\
\text { Procrast. } \\
(\mathrm{N}=61)\end{array}$ & $\begin{array}{c}\text { Woman } \\
\text { Procrast. } \\
(\mathrm{N}=54)\end{array}$ \\
\hline $\begin{array}{l}\text { I often find myself performing tasks that I had intended to do } \\
\text { days before. }\end{array}$ & $33.2 \%$ & $70.5 \%$ & $62.8 \%$ \\
\hline I do not do assignments until just before they are to be handed in. & $29.9 \%$ & $65.3 \%$ & $55.3 \%$ \\
\hline $\begin{array}{l}\text { When I am finished with a library book, I return it right away } \\
\text { regardless of the date it is due. }\end{array}$ & $26.1 \%$ & $53.9 \%$ & $50.8 \%$ \\
\hline $\begin{array}{l}\text { When it is time to get up in the morning, I most often get right } \\
\text { out of bed. }\end{array}$ & $29 \%$ & $61.8 \%$ & $54.8 \%$ \\
\hline I usually make decisions as soon as possible. & $31.2 \%$ & $64.9 \%$ & $60.2 \%$ \\
\hline I generally delay before starting on work I have to do. & $37 \%$ & $78.7 \%$ & $70.1 \%$ \\
\hline I usually have to rush to complete a task on time. & $32.5 \%$ & $66.4 \%$ & $63.9 \%$ \\
\hline $\begin{array}{l}\text { In preparing for some deadline, I often waste time by doing } \\
\text { other things. }\end{array}$ & $34.2 \%$ & $73.7 \%$ & $63.9 \%$ \\
\hline I prefer to leave early for an appointment. & $30.1 \%$ & $62.1 \%$ & $58.8 \%$ \\
\hline I usually start an assignment shortly after it is assigned. & $33.3 \%$ & $68.04 \%$ & $65.3 \%$ \\
\hline I often have a task finished sooner than necessary. & $33.3 \%$ & $69.6 \%$ & $63.9 \%$ \\
\hline I usually accomplish all the things I plan to do in a day. & $30.8 \%$ & $62.8 \%$ & $60.5 \%$ \\
\hline I am continually saying "I’ll do it tomorrow”. & $35 \%$ & $73.2 \%$ & $67.2 \%$ \\
\hline $\begin{array}{l}\text { I usually take care of all the tasks I have to do before I settle } \\
\text { down and relax for the evening. }\end{array}$ & $31.9 \%$ & $65.3 \%$ & $62.5 \%$ \\
\hline $\begin{array}{l}\text { Did so many other things that there was insufficient time left } \\
\text { for studying. }\end{array}$ & $34.1 \%$ & $75.1 \%$ & $62.5 \%$ \\
\hline Forgot to prepare things for studying. & $34.4 \%$ & $74.7 \%$ & $63.9 \%$ \\
\hline Had doubts about your own ability. & $35.6 \%$ & $74.7 \%$ & $68 \%$ \\
\hline Found the subject matter boring. & $34.7 \%$ & $71.8 \%$ & $67.3 \%$ \\
\hline
\end{tabular}

Another research result is the narrative of the academic hope students use the Hope interview. The academic hope students expressed in narrative studies indicate that 50 students have high hope of value, in particular, the value of physics and mathematics. 
The results of this study also showed that the student's academic hope of SMA Kristen 2 Kupang is unique because it is not directly related to themselves, but it is more to God (15 students) and parents (11 students) them. In addition, two students have hope to help a friend who is not as fortunate as they are, and one student who hopes teachers are more patient when teaching him. The uniqueness is illustrated in table 7 and Figure 2.

\section{Table 7}

Result of student's academic hope

\begin{tabular}{|c|c|c|}
\hline Name & Results of Narrative Data & Coding \\
\hline $\begin{array}{l}\text { M.A.C. } \\
\text { J.K }\end{array}$ & $\begin{array}{l}\text { I can be responsible for doing the task because it is essential as a } \\
\text { form of responsibility to God. }\end{array}$ & SP-XMIA.1 \\
\hline R.E.J.M & $\begin{array}{l}\text { I can determine which priorities are and can divide the time well } \\
\text { for the Lord. }\end{array}$ & SP-XIIIS.1 \\
\hline P.M.N & I have high values, achievements for God and others. & SP-XIIMIA.1 \\
\hline A.E.P.A & $\begin{array}{l}\text { I am a useful person for the nation and the people, proud of parents, } \\
\text { especially God. }\end{array}$ & SP-XIIMIA.2 \\
\hline R.K.H & Can live the days well, and do not forget to be grateful. & SP-XIMIA.1 \\
\hline I.C.L & $\begin{array}{l}\text { I can get closer to God and what I do only for God because of the } \\
\text { Lord who created me. }\end{array}$ & SP-XMIA.1 \\
\hline H.A.B & I want to be a child who is more of the fear of the Lord. & SP-XMIA.1 \\
\hline A.J.E.T & I can graduate with a value that boasts parents. & SP-XMIA.2 \\
\hline H.G.W & I want to boast of parents and easily enter university. & SP-XIIMIA.2 \\
\hline S.P.H & I can maintain and improve my value to make my father proud. & SP-XIMIA.2 \\
\hline J.V.C.H & $\begin{array}{l}\text { Graduating with good value, getting a scholarship so as not to } \\
\text { trouble my parents. }\end{array}$ & SP-XIIMIA.2 \\
\hline A.N.P.K & $\begin{array}{l}\text { I want to get good value and show to parents that their struggle } \\
\text { for me is not wasted. }\end{array}$ & SP-XIIS.1 \\
\hline S.D.T.A & $\begin{array}{l}\text { Can be more organized in the task, have time to study in order to } \\
\text { improve the value for the sake of pleasing parents. }\end{array}$ & SP-XIMIA.1 \\
\hline S.G.F.T & $\begin{array}{l}\text { Got enough value to be able to get a scholarship and not burden } \\
\text { my parents. }\end{array}$ & SP-XIIMIA.2 \\
\hline R.J.F.S & $\begin{array}{l}\text { I can make parents proud of me, successfully meeting the father, } \\
\text { being more focused, and unaffected by friends. }\end{array}$ & SP-XIIMIA.1 \\
\hline W.P.B & In order for my values to be better to make my parents proud. & SP-XIIMIA.1 \\
\hline R.Y.B.G.M & $\begin{array}{l}\text { May my values be better, seriously and continue to learn, and involve } \\
\text { and submit all to God. }\end{array}$ & SP-XIMIA.1 \\
\hline A.D.H & Become better in terms of spiritual and economic. & SP-XIIMIA.2 \\
\hline E.I.D & $\begin{array}{l}\text { I hope to understand each lesson well and get good results because } \\
\text { it is as thanksgiving for what God has given. }\end{array}$ & SP-XIIS.1 \\
\hline Y.D.M.M & $\begin{array}{l}\text { I want all values above the KKM, always learning vigorous, and } \\
\text { always rely on God. }\end{array}$ & SP-XIIIS.2 \\
\hline
\end{tabular}




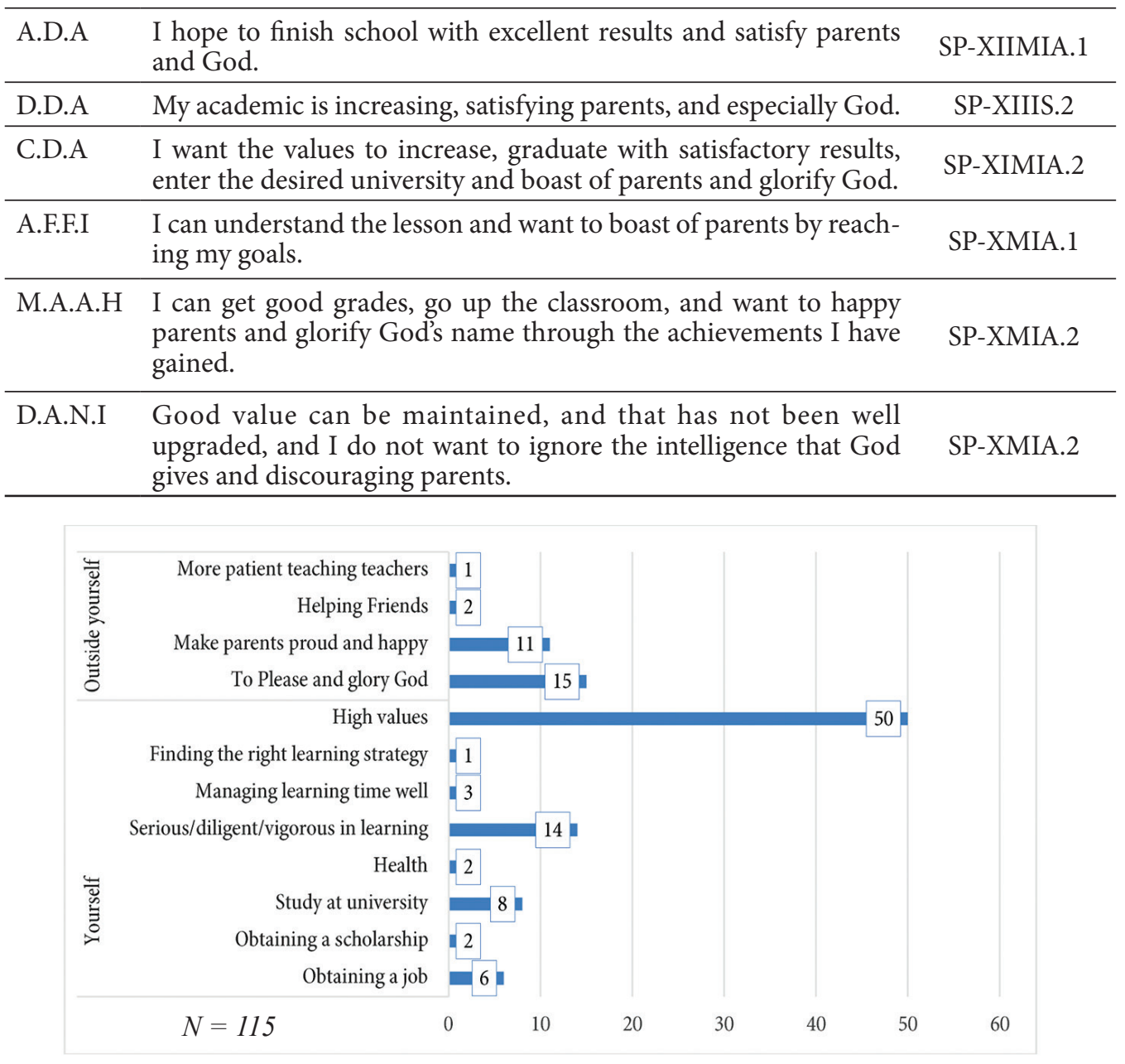

Figure 2. Recapitulation results of student's academic hope

\section{Discussion}

The research aims (1) to investigate the correlation of academic hope with academic procrastination; (2) to determine the differences in the academic procrastination of both men and women; (3) To understand why students conduct academic procrastination; and (4) to know the academic hope of students. The results of the study relating to the first research question show the academic hope has a positive and significant correlation with academic procrastination, as well as its components, except delaying. These findings are similar to the research done by Alexander \& Onwuegbuzie, 2007; Akmal, Arlinkasaria, \& Fitriani, 2017). The second research question, the findings suggest that there is no significant difference between men and women in each of the scales of academic hope 
and academic procrastination. The findings confirm the research done by Synder (1994), Rehmae et al. (2014); Hasnain, Wazid, \& Hasan (2014), relates to academic hope while relating to academic procrastination similar to the research of Abu (2012) and Sharma \& Kaur (2011). Answering the third research question, found the reason students are procrastination is "I generally delay before starting on work I have to do." These reasons are then traced more specifically, and there are three main themes of students conducting procrastination, namely a lack of regulatory skills, working under pressure, and active procrastination. Finally, the dominant student's academic hope of SMA Kristen 2 Kupang is has a high score, but on the other hand, it shows uniqueness because it is not directly related to themselves, but relates to God and parents.

Students with high academic hope have more positive thoughts than negative thoughts every day, and they are more likely to achieve goals than students who have low academic hope. Even they can overcome the difficulties and can navigate the obstacles around to reach the goal successfully (Gallagher, Marques, \& Lopez, 2017). Students with high levels of hope will show a strong feeling of confidence, have life satisfaction and have a low level of depression. Conversely, students who have less hope, they are not able to forget their mistakes and also when they face pressure they tend to be less sought (Baran, Etemadi, \& Karami, 2012). The results show that lack of hope is one of the main reasons for academic procrastination (Mohammadipour \& Rahmati, 2016). Other research results show that high hope levels, fewer academic procrastination or in other words the hope of reducing academic procrastination (Alexander \& Onwuegbuzie, 2007; Tripathi, et al., 2015; Akmal, Arlinkasaria, \& Fitriani, 2017). Hope is a psychological variable that has a very significant relationship with the academic performance and retention of students (Gallagher et al., 2017). Students with high academic hope will be actively engaged in academic activities. They will demonstrate high academic performance, while when the hope is lacking, students are not actively involved in academic activities such as completing homework, communicating with the teacher, and engaging in discussions relevant to subjects topics (Yoon et al., 2015).

One characteristic of students who have academic hope is students who pursue future goals (Ericsson, 2000). Students with high academic hope are more creative in finding the alternative way to achieve their goals, and they are more motivated to pursue them, and consider the burden as a challenge and believe that they can learn from failures and past successes to achieve future goals, they chose goals that allowed more effort. Even students believe in skills, goals, and focus on them (Anthony, Ong \& Bergman, 2006). Students who are dominated by positive feelings will gain pleasure from what they are working on because they feel challenged to evaluate their ability to be more earnest in their work (Olanrewaju, 2010). In the context of this study, students who like this will enjoy doing academic assignments and able to reduce the academic procrastination when they are working on or dealing with these academic tasks in order to achieve future their goals.

The current study results show that there is no difference in academic hope in men and women. This indicates that many factors affect the development of academic hope 
students. The study of Hartanto, Kartadinata, \& Ilfiandra (2019) states there are factors, such as parents, school, teacher support, peer-to-peer, education and personality aspects. In this study, the most dominant factor was the school, the support of teachers, and peers. These three factors tend to emphasize the importance of the group and its values, situational influence on personal behaviour, and sensitivity to external factors (Landrine, Klonoff, \& Brown-Collins, 1992). It also happens to academic procrastination. The fact that academic procrastination does not change according to gender, and also the fact that most previous studies report that the academic procrastination level of men and women is the same (Ferrari, 2010; Schouwenburg, 1992; Haycocks, McCarthy, \& Skay, 1998; Hess, Sherman, \& Goodman, 2000; Johnson \& Bloom, 1995; Rothblum et al., 1986; Watson, 2001; \& Mahasneh, Bataineh, \& Al-Zoubi, 2016).

Based on quantitative data, the reason for supporting the highest academic procrastination both male and female is "I generally delay before starting on work I have to do". Data interviews correlate that the reason for students " supporters stated that "I generally delay before starting on work I have to do", includes three main themes: a lack of regulatory skills, working under pressure, and active procrastination. First, students cannot control their behaviour in managing learning time. Descriptive statistical data and academic procrastination profile reported that $53 \%$ of students had poor time management. Park (2008), stating that students who have poor time management are students who have a lot of time to do other things like spending time with social media rather than preparing and completing academic assignments. This condition is similar to that of research's Ojo (2019) on all secondary schools in Nigeria. This proves that students cannot manage time, effort, and attention to the disruptions faced and do not have a strong commitment to achieving the goal. In this study, the most dominant male student reported did so many other things that there was insufficient time left for studying (75.1\%). In accordance with the interview data, many students report that they work better if under pressure. They say that they stay focused on the task and make themselves more motivated to complete the task when it is in a limited amount of time before the due date. The results of the interview show claim that the benefits of delays could be the reason for unplanned delays beforehand. In this context, procrastinators may pretend to state that it works better under pressure to justify unwanted behaviour by them. It is possible because quantitative data reported that both male students $(74.7 \%)$ and women (68\%) have doubts about their abilities, and $67.3 \%$ of female students find boredom in subjects. In effect, they worked on academic assignments at the last minute, assuming more focused and concentrated. This condition suggests that the claimed benefits of procrastination by procrastinators seem to signify the consequences of procrastination, not the motive for procrastination.

Based on the hope-interview data, most students have the hope to obtain a high value. Hope like this is a hope that is still very common. The uniqueness is seen, when the academic hope of the students is presented to others, as found in this study, namely God, parents, friends, and teachers. The greatest contribution there is to God (15 students) and 
parents (11 students). This finding complements Synder's theory of hope. Synder only develops the hope framework on cognitive aspects, consisting of two components, the agency and the pathways. The first shows a strong determination regarding the achievement of goals in the past, present, and future, while the second is the development of plan or strategy to accomplish that goal (Thakur, 2018). In this view, hope is egocentric concerning a person's perception of the purpose of his life, or in other words, hope in the present context objectivity is not linked to the purpose of the appropriate influence of the sources external to a person, but more than that it is subjectivity defined as a person assesses their agency and pathways about the purpose (Synder et al., 1991). These findings state that external sources (God and parents) have a significant influence on hope so that students have the academic hope to please and glorify God and make parents proud and happy. This is the characteristic of students who have a self-interdependent concept having the ability to adapt and maintain interpersonal relationships with other individuals (God and parents), for them, life would be meaningful if placed in the context of social relations with the people around them. Thus students who have self-interdependent tend to understand other people's actions by connecting them continuously to the context of external actions, and not seeing them using the internal attribution framework (Efruan et.al., 2020). Thus students who have a good spiritual and religious life (self-interdependent) are students who have academic hope to please and glorify God.

Many people believe that academic achievement comes from intelligence and diligent study (Kitjaroonchai \& Hungyo, 2017). The results show that religious have a positive influence on academic achievement, which is religious to strive to work hard, productive, cautious (prudent), and healthy-minded in all actions (sober), and all these qualities tend to bring success in life. Even religious and spiritual provide a source for students to resolve conflicts and self-development with a clear goal, and the student is motivated to achieve personal goals (Mooney, 2010; Erickson \& Phillips, 2012; Kitjaroonchai, 2015). The high level of spirituality will make students happier, live more qualified, satisfied with life, and tend to interpret life positively (Dami et al., 2019). The religious influence on achievement is evidenced through the results of The Computer-Based National Exam (UNBK) April 2018, which suggests that SMA Kristen 2 Kupang ranks three with an average value of 61.9 (IPA) and ranked fourth with an average value of 56.18 (IPS) in East Nusa Tenggara Province, Indonesia. In the year 2019, SMA Kristen 2 Kupang was ranked fourth (IPA), ranked sixth (IPS), and ranked $2^{\text {nd }}$ in Kupang City, East Nusa Tenggara, Indonesia. In relation to academic procrastination, religious students believe that their problems are in the hands of God, and they can reduce self-regulatory issues because procrastination is the essence of self-regulatory failures (Rebetez et al. 2018; Zarzycka, Liszewski, \& Marzel, 2019).

Studies have shown that there is the relationship between hope and spiritualityreligiosity (Nadi \& Ghahremani, 2014; Ottaviani et al., 2014; Hosseini et al., 2017; Rose et al., 2018). The spiritual dimension of consideration is relevant with meaning to live, and as a resource for hope (Souza et al., 2017), or in other words, spirituality-religiosity 
gives meaning and hope in life so that life events are interpreted more positively and have a fundamental role in overcoming the difficulties experienced by the students (Oliveira et al., 2012). The principle through spirituality-religiosity, hope, as a force, can endure against the impact of acute negative life events experienced by students. High academic hope students have positive thoughts than negative thoughts on a daily basis. Students who like this will achieve the expected objectives and can navigate the difficulties and obstacles that exist around to achieve the goal successfully (Synder, 2002).

\section{Conclusions}

The current study results show that: (1) Academic hope has a positive and significant correlation with academic procrastination, as well as its components, except delaying; (2) There is no significant difference between men and women in every scale of academic hope and academic procrastination; (3) The reason students conduct procrastination is "I generally delay before starting on work I have to do." These reasons are then traced more specifically, and there are three main themes of students conducting procrastination, namely a lack of regulatory skills, working under pressure, and active procrastination; and (4) The academic hope students show uniqueness because it is not directly related to themselves, but relates to God and parents.

\section{References}

Abu, Ghazal. M. (2012). Academic procrastination: prevalence and causes from the point of view of undergraduate students. Jordan J Edu Sci., 8(2), 131-49.

Akpur, Ugur. (2017). Predictive and explanatory relationship model between procrastination, motivation, anxiety and academic achievement. Eurasian Journal of Educational Research 69, 221-240.

Akmal, SK, Fitri Arlinkasari, F., \& Fitriani, A. U. (2017). Hope of success and fear of failure predicting academic procrastination students who working on a thesis. Guidena: Jurnal Ilmu Pendidikan, Psikologi, Bimbingan dan Konseling, 7(1), 78-86.

Alvi, Mohsin, H., \& Mirza, M. H. (2018). Difference in level of hope in terms of gender and age.

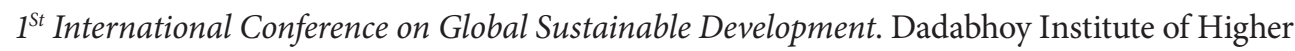
Education, Karachi, Sindh, Pakistan.

Alexander, E.S., \& Onwuegbuzie, A.J. (2007). Academic procrastination and the role of hope as a coping strategy. Personality and Individual Differences, 42(7), 1301-1310. https://doi.org/10.1016/j. paid.2006.10.008

Anthony, D., Ong, L., \& Bergeman, E. (2006). Hope as a source of resilience in later adulthood. Personality and Individual Differences, 41(2), 1263-1273. 
Aremu, A., Williams, T., Adesina, F. (2011). Influence of academic procrastination and personality types on academic achievement and efficacy of in-school adolescents in Ibadan. IFE Psychologia: An Inter J., 19(1), 113-93.

Asif, MA (2011). Clinical implication of academic procrastination. A doctoral project submitted to the faculty of the California School of professional psychology in partial fulfillment of the requirements for her degree of doctor of psychology at Alliant International University, Los Angeles.

Balkis, M., \& Duru, E. (2009). Prevalence of academic procrastination behavior among pre-service teachers, and its relationship with demographics and individual preferences. $J$ Theory Pract Edu, 5, 18-32.

Baran, O., Etemadi, \& Karami. (2012). The impact of hope therapy on achievement motivation of male students of Baharestan. Knowledge and research in applied psychology, 2(43), 3-9.

Brinthaupt, T. M, \& Shin, C. M. (2001). The relationship of academic cramming to flow experience. College Student J., 35(3), 457-72.

Creswell, J. W., \& Plano-Clark, V. L. (2007). Designing and conducting mixed methods research. Thousand Oaks, California: SAGE publications.

Dami, Z. A., Setiawan I., Sudarmanto, G., \& Lu, Y. (2019). Effectiveness of group counseling on depression, anxiety, stress and components of spiritual intelligence in student. International Journal of Scientifice Technology Research, 8(9), 236-243.

Efruan, E. M. C., Dami, Z. A., Latupeirissa, D. S., \& Dethan, M. A. P. (2020). Multicultural counseling with the technique of parable: a diacognitive analysis. European Journal of Science and Theology, 16(1), 165-176.

Erikson, E. H. (2000). The Erik Erikson reader (R. Coles, Ed.). New York: W.W. Norton.

Erickson, L. D., \& Phillips, J. W. (2012). The effect of religious-based mentoring on educational attainment: More than just a spiritual high? Journal for the Scientific Study of Religion, 51(3), 568-587.

Esmaeili, N., \& Monadi, M. (2016). Identifying the causes of academic procrastination from the perspective of male middle school male students. International Journal of Humanities and Cultural Studies, Special Issue, 2464-2487.

Ferrari, J. R., \& Tice, D. M. (2000). Procrastination as a self-handicap for men and women: A task avoidance strategy in a laboratory setting. Journal of Research in Personality, 34, 73-83.

Ferrari, J. R. (2010). Still procrastination: The no-regrets guide to getting it done. New Jersey: Wiley.

Feldman, D. B., Davidson, O. B., \& Margalit, M. (2015). Personal resources, hope, and achievement among college students: The conservation of resources perspective. J Happiness Stud, 16, 543-560. doi: 10.1007/s10902-014-9508-5

Gallagher, M. W., Marques, S. C., \& Lopez, S. J. (2017). Hope and the academic trajectory of college students. J. Happiness Stud, 18, 341-352. doi: 10.1007/s10902-016-9727-Z

Gul, M., \& Nizami, N. (2015). Gender differences on hope and psychological well-being among the parents of differently abled children. The International Journal Humanities and Social Study, $3(9), 1-4$.

Hartanto, D., Kartadinata, S., \& Ilfiandra, A. (2019). The uniqueness of students' academic hope in Indonesia. International Journal of Scientific\& Technology Research, 8(4), 107-112. 
Hasnain, N., Wazid, S., \& Hasan, Z. (2014). Optimism, hope, and happiness as correlates of psychological well-being among young adult Assamese males and females. IOSR Journal of Humanities and Social Science, 19(2), 44-51.

Haycock, L. A., McCarthy, P., \& Skay, C. L. (1998). Procrastination in college students: The role of self-efficacy and anxiety. Journal of Counseling \& Development, 76(3), 317-24. http://dx.doi. org/10.1002/j.1556-6676.1998.tb02548.x

Hess, B., Sherman, M. F., \& Goodman, M. (2000). Eveningness predicts academic procrastination: The mediating role of neuroticism. Journal of Social Behavior \& Personality, 15(5), 61-74.

Holt, J., \& Reeves, J. S. (2001). The meaning of hope and generic caring practices to nurture hope in a rural village in the Dominican Republic. Journal of transcultural nursing, 12(2), 123-131.

Hosseini, S., Nasrolahi, B., \& Aghili, M. (2017). Prediction of hope of life based on spiritual well-being and psychological hardiness in women with breast cancer. Arch Breast Cancer, 4(4), 136-140. doi: 10.19187/abc.201744136-140

Johnson, J. L., \& Bloom, A. M. (1995). An analysis of the contribution of the five factors of personality to variance in academic procrastination. Personality and Individual Differences, 18, 127-133.

Kandemir, M. (2014). Reasons of academic procrastination: Self - regulation, academic self-efficacy, life satisfaction and demographics variables. Procedia-Social and Behavioral Sciences, 152, 188-193.

Kitjaroonchai, N., \& Hungyo, E. (2017). The relationship between students' involvement in moral and religious activities and their academic achievement at a faith-based institution: Evidence from Thailand. Catalyst, 15(2), 1-13.

Kitjaroonchai, N. (2015). The correlation between student's academic achievement and ethical and moral activities involvement in a Christian institution. Catalyst, 12(2), 24-33.

Krathwohl, D. R. (1998). Methods of educational and social science research: An integrated approach (2nd. Ed.). New York: Longman.

Knaus, W. (2002). The Procrastination workbook. Oakland, CA: New Harbinger Publication Inc.

Landrine, H., Klonoff, E. A., \& Brown-Collins, A. (1992). Cultural diversity and methodology in feminist psychology: Critique, proposal, and empirical example. Psychology of Women Quarterly, 16, 145-163. Lay, C. H. (1986). At least my research article on procrastination. Journal of Research in Personality, 20, 474-495.

Mahasneh, A. M., Bataineh, O. T., \& Al-Zoubi, Z. H. (2016). The relationship between academic procrastination and parenting styles among Jordanian undergraduate university students. The Open Psychology Journal, 9, 25-34. doi: 10.2174/1874350101609010025

Marques, S. C., Lopez, S. J., \& Mitchell, J. (2013). The role of hope, spirituality and religious practice in adolescents' life satisfaction: Longitudinal findings. J Happiness Stud, 14, 251-261. doi: 10.1007/ s10902-012-9329-3

Milgram N. (1995). Correlate of academic procrastination discomfort task averseness and task capability. J Psychol, 129, 145-55. http://dx.doi.org/10.1080/00223980.1995.9914954

Mohammadipour, M., \& Rahmati, F. (2016). The predictive role of social adjustment, academic procrastination and academic hope in the high school students' academic burnout. Interdisciplinary Journal of Education, 1(1), 35-45. 
McDermott, D. \& Snyder, C. R. (2000). The great big book of hope. Oakland, CA: New Harbinger Publications.

Moonaghi, Hossein, K., Baloochi, Tahereh, \& Beydokhti. (2017). Academic procrastination and its characteristics: A Narrative review. Future of medical education journal, 7(2), 43-50.

Mooney, M. (2010). Religion, college grades, and satisfaction among students at elite colleges and universities. Sociology of Religion, 71(2), 197-215.

Nábělková, E., \& Ratkovská, J. (2015). Academic procrastination and factors contributing to its overcoming. The New Educational Review, 39(1), 107-118.

Nadi, MA, \& Ghahremani, N. (2014). The relationship between dimensions of religiosity/spirituality with mental health and hope for future between staff of public hospitals in Shiraz. Journal of Education and Health Promotion, 3(20), 12-17.

Narges, R., Kermanian, S., \& Zarei, S. (2014). The effectiveness of group hope therapy on academic procrastination among female university students. J. Appl. Environ. Biol. Sci., 4(8), 259-264.

Ojo, AA (2019). The impact of procrastination on students' academic performance in secondary schools. International Journal of Sociology and Anthropology Research, 5(1), 17-22.

Olanrewaju, Adebayo, S. (2010). Correlation between academic cheating behavior and achievement motivation. Nature and Science, 8(12), 130-134.

Oliveira, W. T., Antunes, F., Inoue, L., Reis, L. M., Araújo, C. R. M. A., Marcon, S. S. (2012). Vivência do cuidador familiarna prática do cuidado domiciliar ao doente crônico dependente. Cienc Cuid Saúde, 11(1), 129-37.

Ottaviani, A. C., Souza, E. N., Drago, N. C., Mendiondo, M. S. Z., Pavarini, S. C. I., Orlandi, F. S. (2014). Hope and spirituality among patients with chronic kidney disease undergoing hemodialysis: a correlational study. Rev Latino-Am Enfermagem, 22(2), 248-54.

Özer, Bilge, Uzun, \& Saçkes, Mesut. (2011). Effects of academic procrastination on college students' life satisfaction. Procedia Social and Behavioral Sciences, 12, 512-519.

Özer, B. U., Demir, A., \& Ferrari, J. R. (2009). Exploring academic procrastination among Turkish students: Possible gender differences in prevalence and reasons. The Journal of Social Psychology, 149(2), 241-257.

Paludi, M., \& Frankell-Hauser J. (1986). An idiographic approach to the study of women's achievements striving. Psychol Women Q, 10, 89-100. http://dx.doi.org/10.1111/j.1471-6402.1986.tb00738.x

Park, S. W. (2008). Self-regulation of academic procrastinators: A mixed method study. Thesis. Department of Educational and School Psychology and Special Education. The Pennsylvania State University.

Pychyl, T. A., Coplan, R. J., \& Reid, P. A. M. (2002). Parenting and procrastination: Gender differences in the relations between procrastination, parenting style and self-worth in early adolescence. Personality and Individual Differences 33, 271-85.

Rabin, L. A., Fogel, J., \& Nutter-Upham, K. E. (2011). Academic procrastination in college students: The role of self-reported executive function. J. Clin Experim Neuropsychol, 33(3), 344-57.

Rebetez, M. M.L., Rochat, L., Barsics, C., \& Van der Linden, M. (2018). Procrastination as a self-regulation failure: The role of impulsivity and intrusive thoughts. Psychological Reports, 121(1), 26-41. 
Rehman, A., Rehman, S., Razzaq, S., \& Wali, A.S. (2014). Relationship between hope and anxiety among university students. European Journal of Psychological Research in Social Science, 2(1), 11-16.

Rose, A. H., Rose, J. R., Miller, R. B., \& Dyer, W. J. (2018). Exploring hope as a mediator between religiosity and depression in adolescents. Journal of Religion \& Spirituality in Social Work: Social Thought, 37(3), 239-253, doi:10.1080/15426432.2018.1488646

Rothblum, E., Solomon, L., \& Murakami, J. (1986). Affective, cognitive, and behavioral differences between high and low procrastinators. Journal of Counseling Psychology, 33(4), 387-94. http:// dx.doi.org/10.1037/0022-0167.33.4.387

Sharma, M., \& Kaur, G. (2011). Gender differences in procrastination and academic stress among adolescents. Indian J Soc Res, 8(2), 122-7.

Schouwenburg, H. C. (1992). Procrastinators and fear of failure: An exploration of reasons for procrastination. European Journal of Personality, 6, 225-236.

Solomon, L. J., \& Rothblum, E. D. (1984). Academic procrastination: Frequency and cognitive behavioural correlates. Journal of Counseling Psychology, 31, 503-509.

Souza, E. N., de Oliveira, N. A., Luchesi, B. M., Aline Gratão, C. M., Orlandi, F. de S., \& Pavarini, S. C. I. (2017). Relationship between Hope and Spirituality of Elderly Caregivers. Texto Contexto Enferm, 26(3), 1-8. http://dx.doi.org/10.1590/0104-07072017006780015

Snyder, C. R., Harris, C., Anderson, J. R., Holleran, S. A., Irving, L. M., Sigmon, S. X., Yoshinobu, L., Gibb, J., Langelle, C., \& Harney, P. (1991). The will and the ways: Development and validation of an individual-differences measure of hope. Journal of Personality and Social Psychology, 60(4), 570-585.

Snyder, C. R. (2002). Hope theory: Rainbows in the mind. Psychological Inquiry, 13(4), 249-275. doi:10. 1207/S15327965PLI1304_01

Thakur, M. B. (2018). Examining the association between hope, optimism, self-esteem and life satisfaction: The Indian Context. Journal of Psychosocial Research, 13(1), 23-31.

Tripathi, S. R., Pragyendu, Kochar, A., \& Dara, P. (2015). Role of self-efficacy and hope in academic procrastination among undergraduate students. Indian Journal of Positive Psychology, 6(4), 376-379.

Van Eerde, W. (2003). A meta-analytically derived nomological network of procrastination. Pers Individ Diff., 35(6), 1401-18.

Watson, D. C. (2001). Procrastination and the five-factor model: A facet level analysis. Personality and Individual Differences, 30, 149-158.

Yıldız, Sevilay, \& Kaya, Y1ldız (2016). The relationship between academic procrastination and hopelessness perceptions of primary school teaching department students. International Online Journal of Educational Sciences, 8(3), 234-251.

Yoon, H. J., In, H., Niles, S. G., Amundson, N. E., Smith, B. A., \& Mills, L. (2015). The effects of hope on student engagement, academic performance, and vocational identity. The Canadian Journal of Career Development, 14(1), 34-45.

Zarzycka, B., Liszewski, T., \& Marzel, M. (2019). Religion and behavioral procrastination: mediating effects of locus of control and content of prayer. Curr Psychol. https://doi.org/10.1007/s12144019-00251-8 


\title{
Prognostinis mokinių akademinio lūkesčio ir mokymosi atidèliojimo ryšys: mišrių metodų tyrimas
}

\author{
Zummy Anselmus Dami ${ }^{1}$, Sance Mariana Tameon ${ }^{2}$, Jeheskial Saudale ${ }^{3}$
}

\author{
Persatuan Guru universitetas, 1945 NTT, Ugdymo fakultetas, Indonezija, ID-85119, zummydami82@gmail.com \\ Pastoracinio konsultavimo katedra, Sekolah Tinggi Agama Kristen Negeri Kupang, Indonezija, ID-85111, \\ sancemariana82@gmail.com \\ 3 Krikščionių religijos ugdymo katedra, Sekolah Tinggi Agama Kristen Kupang, Indonezija, ID-85112, \\ jeheskiel.saudale@gmail.com
}

\section{Santrauka}

Straipsnyje analizuojami šie klausimai: 1) ar yra koks nors ryšys tarp akademinio lūkesčio ir mokymosi atidèliojimo; 2) ar skiriasi skirtingų lyčių mokinių, t. y. vaikinų ir merginų, mokymosi atidèliojimas; 3) kokios yra mokymosi atidèliojimo priežastys; 4) koks mokinių akademinis lūkestis ateityje. Norint atsakyti $\mathfrak{i}$ šiuos tyrimo klausimus, buvo atlikta analizė remiantis mišrių metodų tyrimu, kuriame kiekybinis metodas integruotas kartu su kokybiniu metodu, o išvados daromos remiantis abiem tyrimais. Tyrime dalyvavo 253 antrosios krikščioniškosios privačios Kupango vidurinès mokyklos (SMA Kristen 2 Kupang) mokiniai, iš jų atsitiktinę atrankos imtị sudarė 115 mokinių. Atlikus analizę nustatyta, kad: 1) egzistuoja teigiamas ir statistiškai reikšmingas ryšys tarp akademinio lūkesčio ir mokymosi atidèliojimo, taip pat tarp jo komponentų, išskyrus delsimą; 2) nẻra statistiškai reikšmingo skirtumo tarp skirtingų lyčių, t. y. vaikinų ir merginų, kiekvienoje akademinio lūkesčio ir mokymosi atidèliojimo skaleje; 3) pagrindinè priežastis, kodèl mokiniai atidèlioja mokymąsi, tiek vaikinų, tiek merginų yra tokia: „Aš dažniausiai delsiu prieš pradėdamas(-ama) darbą, kurị turiu padaryti.“ (vaikinų mokymosi atidèliojimo pateisinimai yra šie: „dariau daug kitų dalykų, tad nebuvo pakankamai laiko mokytis“; „pamiršau pasiruošti“; „turẻjau abejonių savo sugebejimais“; merginų mokymosi atidèliojimo pateisinimai yra šie: „abejojau savo sugebejjimais“; „tema pasirodè nuobodi“; „aš nuolat sakau: 'aš tai padarysiu rytoj'“). Apibendrinus tyrimo rezultatus galima teigti, kad pagrindinès priežastys, lemiančios mokymosi atidèliojimą, yra šios: kontrolès ịgūdžių stoka, darbinè ịtampa ir aktyvus delsimas; 4) akademinis mokinių lūkestis pasižymi unikalumu, nes jis nèra tiesiogiai susijęs su jais pačiais, bet turi sąsajų su Dievu ir tėvais.

Esminiai žodžiai: akademinis lūkestis, mokymosi atidèliojimas, mišrūs metodai, atidèliojimo priežastys, lūkesčio unikalumas.

Gauta 20200206 / Received 06022020

Priimta 20200522 / Accepted 22052020 